\title{
Feeding Behaviour of Broiler Chickens: a Review on the Biomechanical Characteristics
}

http://dx.doi.org/10.1590/1516-635x16021-16

Review

\section{Author(s)}

Neves DP

Banhazi TM"

Nääs IA'

School of Agriculture Engineering, State University of Campinas, Cândido Rondon Ave, 501, Brazil

" National Centre for Engineering in Agriculture, Faculty of Engineering and Surveying, University of Southern Queensland, West Street, Toowoomba QLD, 4350, Australia

\begin{abstract}
Feed related costs are the main drivers of profitability of commercial poultry farms, and good nutrition is mainly responsible for the exceptional growth rate responses of current poultry species. So far, most research on the poultry feeding behaviour addresses the productivity indices and birds' physiological responses, but few studies have considered the biomechanical characteristics involved in this process. This paper aims to review biomechanical issues related to feed behaviour of domestic chickens to address some issues related to the feed used in commercial broiler chicken production, considering feed particle size, physical form and the impact of feeders during feeding. It is believed that the biomechanical evaluation might suggest a new way for feed processing to meet the natural feeding behaviour of the birds.
\end{abstract}

\section{INTRODUCTION}

The poultry industry is the most dynamic sector within the global meat business during the last decade, with the greatest growth reflected in the food global demand increase. It is expected that, in the next years, the meat industry will increase production driven by global population growth, especially in developing countries. Chickens and turkeys are the most common sources of poultry meat, but there is also commercially available meat from ducks, geese, pigeons, quails, pheasants, ostriches and emus. Consumer preference also has been changing in many developed countries, characterized by greater demand for low-calorie foods and changes in lifestyle, which reduces the consumer time spent on food preparation. By this approach, the chicken meat highlights and the largest producer countries are United States, China, Brazil and European Union, being Brazil and United States are also the main exporter countries. These two countries together provide two-thirds of global trade (FAO, 2010; FAO, 2012; USDA, 2012).

Feedstuff is an aspect of high economic importance in the rearing of commercial poultry not only because it is primarily responsible for the growth response of birds, but mainly because it represents the largest cost in the production cycle (Ávila et al., 1992). For instance, the broilers' energy requirements are responsible for $70 \%$ of the cost of the ration (Skinner et al., 1992) and, besides, the processing method and the grain type interfere differently on the economic viability and animal performance. The advantages of using processed feed have been well documented, although they represent a high cost for manufacturing. Under natural conditions, birds have to deal with different types of feed, which have different energy and protein levels. Despite domestication and selection for fast growth, broiler chickens did not lose their ability to discriminate different types of diets (Emmans \& Kyriazakis, 2001). It has been suggested that the birds associate the feed physical characteristics 
with nutritional content, which indicates that the contact perception contributes to the identification of the feed.

Most researches on performance and behaviour of broiler chicken feeding has been with respect to productivity indices and physiological responses, but there is a lack of scientific knowledge of the biomechanical features of the bird feeding process. Chickens present cranial kinesis, which is characterized by the movement of the upper jaw in relation to the skull, a key factor in feeding efficiency found in all species of birds (Bock 1964; Zweers 1982; Feduccia 1986; Bout \& Zweers, 2001; Gurd 2006; Estrella \& Masero, 2007; Gurd, 2007). Past and recent publications have reported this feature in many species of fish, rodents and birds, as well as in humans. In domestic chickens (Gallus gallus domesticus); however, even though a few studies are found regarding the biomechanical issues of the intake process, no one is related to the modern captive breed strains for egg or meat production.

This review paper aims to approach what is known to date about the biomechanical features of the feeding behaviour of chickens. It addresses issues related to feed characteristics used in commercial broiler chicken production, with regard to feed particle size, physical form and the influence of feeders.

\section{General concepts of biomechanics and historical context}

Biomechanics can be defined as the study of the mechanical model of the body and its movements, integrating physicsandbiology(Domenici\&Blake,2000), or as the mechanics of movement in living creatures, being a discipline of biology that combines biophysics, physiology, physics, engineering and medicine (Low \& Reed, 1996), or even simple physical (mechanical) movement displayed or produced by biological systems (Mclester \& Pierre, 2008). Despite biomechanics being a relatively young discipline recognized in scientific research, its considerations are also of interest to several other scientific disciplines and professional fields, such as zoology, medical (orthopaedics, cardiology, sports medicine, physiotherapy), biomedical engineering or biomechanics, or kinesiology (study of human movement) (Hall, 1999).

Giovanni Borelli (1608-1679) is considered a pioneer in the studies of biomechanics. He integrated physiology and physical science to describe the human and animal movements, and offered thoughts on the function of muscles. The invention of the light microscope in the latter part of the seventeenth century greatly aided the study of physiology, but the advent of photography in the nineteenth century played a key role, and allowed a more detailed study of human and animal locomotion. Some knowledge of electricity was also developed in this period, which led to the use of electrical stimulation and electromyography. In the twentieth century, the invention of the electron microscope influenced the understanding of mechanical changes on a cellular level (Low \& Reed, 1996).

Currently, biomechanics is seen as an academic subject and with the advancement of computer and microelectronics it is now possible to use measurement systems in more complex fields. High resolution cameras, high storage capacity and digital image processing for a relatively affordable cost make the transformation of qualitative for quantitative techniques possible, with a level of accuracy comparable to traditional punctual measuring methods. In this sense, the high speed camera is an apparatus that has been highlighted for its effectiveness in several areas of study, including animal behaviour assessments.

\section{The study of biomechanics and motion analysis}

In the study of biomechanics, it must be consider the consequences of movements produced by forces, integrating biological features with traditional mechanics (the effect of forces and energy in the motion of bodies). The static and the dynamic are two sub-branches of mechanics used to study the anatomical and functional aspects of living organisms. Static is the study of systems that are in a state of constant motion, i.e. both at rest (without movement) or in motion at a constant speed. Dynamics is the study of systems in which the acceleration is present. Kinematics and kinetics are subdivisions of biomechanical study. Kinematics is the description of motion features including the pattern and velocity of the body segments which generally translates the degree of coordination that an individual displays. Whereas kinematics describes the appearance of movement, kinetics is the study of forces associated with movement (Hall, 1999; Serway \& Jewett, 2004). Anthropometric factors, e.g. size, shape and weight of body segments, are other important concerns in kinetic analysis (Hall, 1999).

Among other essential purposes, animals depend mainly on muscles to propel themselves for locomotion 
and food handling. Muscles are biological motors that consume chemical energy and perform mechanical work. Generally the function of muscles is considered within the 'metabolism' together with other processes, e.g. thermoregulation, which also consumes oxygen and generates heat. The power of muscles is generally viewed only by the capacity of enzyme energy supply. However, the rate at which muscles can perform the work is limited by three variables: the stress it may exercise, the tension and the contraction frequency. These are the mechanical variables, and their maximum values are defined by mechanical limitations (Pennycuick, 1992).

Nowadays biomechanics can be considered a "tool" to investigate matters of ecology, physiology and evolution. It also can be useful for assessments, forecasts and understanding of behaviours. Some structures of animals (e.g. jaw, teeth, claws, beaks and horns) may be regarded as tools and/or weapons with certain physical characteristics, and the kind of forces applied may influence their utilization. These forces can be used to handle, break or tear the food; for different ways of feeding (suction, crushing and handling through the jaw); for biting, cutting the skin, breaking bones or killing (Domenici \& Blake, 2000). Several factors affect the execution of eating action, such as competition, energy consumption, risk of predation, prey availability and predator performance. Performance includes the ability of a predator to locate, capture and manipulate the prey, all being influenced by their morphology (Wainwright, 1991).

Biomechanical studies have been widely investigated using high speed camera technology in various species of animals, e.g. insects (Dangles et al., 2006; Wu et al., 2008; Nguyen et al., 2010; Truong et al., 2012); fish (Korff \& Wainwright, 2004; Herrel et al., 2005; Huber et al., 2008; Wroe et al., 2008; Huber et al., 2009; Mara et al., 2009; Habegger et al., 2010; Tran et al., 2010); rodents (Bracha et al., 2003; Sakatani \& Isa, 2004; Herbin et al., 2007; Morita et al., 2008; Beare et al., 2009; Fu et al., 2009; Stefen et al., 2011); reptiles (Deban \& O'Reilly, 2005; Herrel \& O'Reilly, 2006; Fuller et al., 2011; Schaerlaeken et al., 2011); birds (Westneat et al., 1993; Estrella \& Masero, 2007; Abourachid et al., 2011; Dawson et al., 2011; Smith et al., 2011); as well as in humans (Arampatzis et al., 1999; Yoganandan et al., 2002; Imura et al., 2008; Shan, 2008; Bakker et al., 2009; Steeve, 2010). The main topics treated are flight features, bite force analysis, cognitive functions assessments by realtime tracking, anatomical and physiological study of locomotion, evaluation of mandibular motion and muscle activity during ingestion or vocalization, the effect of food type on feeding efficiency, 3-D bones reconstruction for motion morphology assessments, among others.

At some time, several reasons induced the domestication of birds. These include: communication (pigeon); vestment (ostrich), sport (falcon), decoration (peafowl), religion (Egyptian goose); and pet (cage birds). Nowadays, the main aims of domestication are egg and meat production. Economically, these activities are very important, since producing poultry meat, and eggs are very efficient ways to transforming vegetable mass into meat protein (FAO, 2010). In the upper limbs, the birds have wings moved by powerful pectoral muscles, consisting of a very well developed structure and the skeletal bones are significantly lighter. These features have given the birds a high mobility, allowing their dispersion throughout the environment and consequently their adaptation to a variety of environments. These adjustments led to different types of secondary anatomic variations of the beak, oral cavity, feathers, wings, legs and feet (King, 1986). Thus, a better comprehension of the biomechanics of each element is helpful for studying disease aetiology, and for making treatment decisions and general motion assessments.

On the other hand, some methodological drawbacks could be encountered when it is necessary to adopt a surgical intervention for implant insertion, which could involve ethical concerns and technological limitations (Bergmann et al., 2001; Stansfield et al., 2003), beyond the stress to which the individual could be subjected. In addition, the labour intensiveness, utilization of electrical stimulation and post mortem examination can lead to a non-real situation, such as the lack of functional movements (Gussekloo et al., 2001). Developing a precise and non-invasive method for measuring the internal force within the living body still remains a great challenge in the field of biomechanics and motion analysis (Lu \& Chang, 2012). Motion analysis can be an effective method for identifying beneficial and damaging elements when a moving system of a living organism is performing a task. Some advantage via the utilization of high speed cameras and computational image analysis for motion assessments has been achieved, especially with respect to its relatively low cost, versatility in analysis, commercial availability of the hardware and possibility of system upgrade according to need (Sakatani \& Isa, 2004). 


\section{Chicken intake process: anatomical and biomechanical approaches}

The digestive system of the chicken is considered simple, short and extremely efficient. The beak collects the food, and the bird decides whether to accept or reject it through the tactile cells. This decision is based on reflectivity and taste, even though the number of taste buds is small. No evidence has been produced to suggest that chickens have any real ability to smell. The food is swallowed whole with a little saliva, through the oesophagus to the crop, in which the fibre is softened, and the food is acidified by lactic acid. From the crop, the food passes into the proventriculus, which secretes acid and pepsin, an organ that best resembles the stomach of a mammal. Thereafter the food passes into the gizzard, an organ with powerful muscles that contract rhythmically to reduce the thickness of the content. After that, the food passes through various regions of the intestine by peristaltic contractions, and it is at this stage that digestion and nutrient absorption occur. The digestion also occurs to a lesser extent in the caeca, two bags that are located at the junctions of the small and large intestines, the latter being responsible for the absorption of water. From here the faeces move into the cloaca for evacuation, which is also related to the excretion of urine, acceptance of delivery of sperm and the passage of egg outwards (Sainsbury, 1980).

The birds have one of the most skilled skulls of living vertebrates, besides the pneumatisation by epithelial extensions of air sacs, a fact that allows alleviates the weight, they are kinetic. The cranial kinesis is related to the movement of the upper jaw, or part of it, in relation to the skull, which is a characteristic found in all species of birds (Bock, 1964; Zweers, 1982; Feduccia, 1986; Bout \& Zweers, 2001; Gussekloo \& Bout, 2005). This is not an exclusive feature of birds, as it is also found in fish, reptiles and amphibian fossils (Bock, 1964). The skull of birds can be divided into functional units: the braincase, the upper jaw, the bone structure that comprises the palate, the jugal bar and quadrate, and the lower jaw. These functional units operate together in which the quadrate bone plays a key role during the beak movement (Van Den Heuvel, 1992).

There are many proposed functions of cranial kinesis which can be highlighted: the highest elevation of the upper jaw, reducing the force required to open the beak, keeping the beak closed without muscular effort, higher beak closing speed, shock absorption, increased capacity of food selection, maintenance of the primary axis of orientation and attachment of the buccal apparatus muscles (Bock, 1964; Bout \& Zweers, 2001; Gurd, 2006; Estrella \& Masero, 2007; Gurd, 2007). Furthermore, the cranial kinesis can be uncoupled or coupled. Uncoupled is when the upper and lower jaws move independently. Coupled kinetics occurs owing to two separate mechanisms, or a combination of both. In most birds, the presence of postorbital ligaments and the lacrymomandibular is the main morphological feature of this system. When one of these ligaments is stretched to the maximum, the lower jaw cannot be depressed without the quadrate bone swinging forward while the opposite occurs in beak closing motion, establishing a relationship of dependence of both upper and lower jaws, although a certain degree of independence in this mechanism may exist (Bock, 1964).

The domestic fowl has a prokinetic skull mainly characterized by a postorbital ligament, also known as the squamosomandibular ligament, whereby the skull connects with the mandibular process. Other species can also present rhincokinetic or amphikinetic skulls, differing in the location of the jaw joint. Therefore, the chicken jaw is a unique structure that moves entirely. When the beak is usually closed, the ligaments are not tensioned, and the system is considered at rest. The coupled cranial kinesis in domestic fowl does not play a dominant role in the feeding process. The jaw is lowered $20 \mathrm{~ms}$ after the lifting of the upper jaw, indicating that the coupled cranial kinesis does not occur while the food is grasped, but can occur eventually. Similar characteristics may occur in subsequent cycles for the transport of food into the oral cavity during the food manipulation. However, the coupled kinesis is used when the bird closes its beak, as it is not possible to depress the upper jaw without raising the lower jaw (Van Den Heuvel, 1992).

The feeding behaviour of animals can be divided into appetitive phases, corresponding to the demand for feed and consummatory act, which is the real feed intake. The assessments may be related to bite events and/or visits to feeders (Slater, 1974; Berdoy, 1993; Nielsen, 1999) in which these could be considered as a unit to analyze feeding behaviours (Nielsen \& Whittemore, 1995). There is no real chewing in birds, the tongue is rigid and tactile sensibility is mainly perceived when the particles are touched and seized by the beak tip (Picard et al., 2002). The appetitive phase of chickens can be characterized by the foraging behaviour, which is the time that the bird explores the environment searching for food, as reported by (Yo et al., 1997), who found that two thirds of young bird pecks do not result in the prehension of a feed particle. 
The mechanical process of feeding in domestic chicken is similar to that of pigeons (Table 1). It is suggested that, within the phases 'grasp' and 'mandibular motion', the opening beak amplitude is gauged according to the particle size and the initial beak opening is used to control the amplitude. For the 'grasp' phase, the birds use visual information and for 'mandibular motion' tactile information. Moreover, the feeding behaviour of these birds can be defined as stereotyped movement patterns. These stereotyped patterns create an eating-response sequence and such sequences create an event feeding scene or a feeding bout (Figure 1). The reason why these movements are defined as stereotyped is on account both of duration and temporal organization of the variables in the process. This standard is based on the Variation Coefficient. Considering the appearance of stereotyped variables that compose a feeding scene of pigeons (Zweers, 1982) and chickens (Van Der Heuvel \& Berkhoudt, 1998), the feeding behaviour can be considered as a result of Fixed Action Patterns, more than just a pattern. Actually, the bird can adapt certain movement patterns depending on the type of food, but such behaviours are subordinate to limitations of morphological structure and mechanical construction (Zweers, 1982).

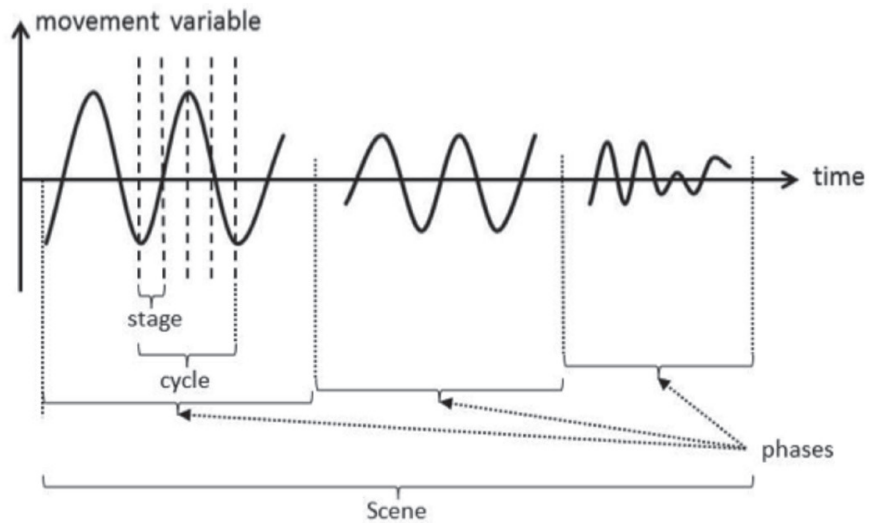

Figure 1 - Schematic representation of the subdivision of a feeding behaviour pattern. Adapted from Zweers (1982).

A better understanding of the patterns of biomechanical mechanisms involved in the bird intake process is important. Commercially farmed birds are not well documented subject. Nevertheless, this knowledge could lead to a better understanding of the feeding process, focusing on maximizing performance and animal welfare at farm level, since ration has a high impact on farm profitability.

\section{Feed: the raw material, processing methods and the physical form}

The production of feed for livestock aims at reducing the cost of the manufacturing process without compromising the quality of the final product.

Table 1 - Summarized description of the phases of the pigeon and chicken feeding scenario.

\begin{tabular}{|c|c|}
\hline Phase & Description \\
\hline Fixation & $\begin{array}{l}\text { The head still stable above the seed, the eyes wide open. The distance between the eye and the target is about } 5-8 \mathrm{~cm} \text {. Beak } \\
\text { is closed, but fluctuations could be seen in the openings of the beak and tongue movements for swallowing seeds ingested } \\
\text { previously. }\end{array}$ \\
\hline Approach or pecking & $\begin{array}{l}\text { Starts when the bird moves its head uninterruptedly towards food in an oblique or vertical direction. The beak opens, and the } \\
\text { elevation of the upper jaw occurs prior to the depression of the lower jaw and the tongue is retracted. The beak opens slightly } \\
\text { more than the seed size. The eyes are partially closed. }\end{array}$ \\
\hline Grasping & $\begin{array}{l}\text { Starts with the maximum beak opening in the last part of the approach phase. The beak tip apprehends the seed and the eyes } \\
\text { are completely closed. }\end{array}$ \\
\hline Withdrawal & $\begin{array}{l}\text { Starts right after the 'grasping' phase. Food is retained in the beak tip, and head is withdrawn in an upward motion. There may } \\
\text { be a delay when the beak strikes against the substrate. }\end{array}$ \\
\hline Stationing & $\begin{array}{l}\text { The food is eventually repositioned by "catch-and throw" movements. These serve to reposition the seed in the beak before } \\
\text { starting the transport. This phase can be repeated as often as needed or possibly skipped when seed is properly grasped. }\end{array}$ \\
\hline Transporting & $\begin{array}{l}\text { Transports the seed from the beak tip into the pharynx level though the "catch-and-throw" or "slide-and-glue" movements or } \\
\text { a combination of both. The "slide-and-glue" technique, usually adopted with smaller particles, consists in the displacement of } \\
\text { the tongue up to the tip of the beak in order to glue the food with the aid of the sticky saliva and convey it into the oral cavity. }\end{array}$ \\
\hline Collecting & Small seeds are accommodated at the base of the tongue while the bird keeps feeding. It does not occur with large seeds. \\
\hline Swallowing & $\begin{array}{l}\text { Final transportation of the seed into the esophagus with one or more movements of the pharynx, tongue, small beak openings } \\
\text { and head jerks. Two mechanisms: "scraping" which is the continuation of "slide-and-glue" for small seeds and "peristaltic" } \\
\text { which is a continuation of "catch-and-throw" for larger seeds. }\end{array}$ \\
\hline
\end{tabular}

Adapted from (Moon \& Zeigler, 1979; Zeigler et al., 1980; Zweers, 1982; Bermejo et al., 1989; Van Der Heuvel \& Berkhoudt, 1998). 
Amongst the purposes of feed processing, there are mostly the changes of particle size and increased density of feed. A key factor in the processing is to obtain the maximum nutritional potential of the feed at minimal cost (Thomas et al., 1998). This is achieved by altering the natural state of ingredients to improve their nutritive potential, and, therefore, the pelleting process is most widely used by the livestock feed industry (Meurer et al., 2008). Generally the rations for broiler chickens are offered in mash, pelleted, extruded or crumbled physical forms. The mash rations are processed in the form of crumbs by mixing ground ingredients and also form the raw material for other varieties of ration. The pelleted type is the mash one which is pressed under high temperature, pre-cooked and subsequently moulded in the shape of small cylinders, so called pellets. The extruded rations are composed of mash ration subjected to baking at high pressure, humidity and temperature, but such processes are applied in a short time compared with that of pelleted ones. Finally, the crumbled rations are those pelleted or extruded which are crushed to form particles larger than those of mash feed and smaller than pellets (Thomas et al., 1998). Also, in addition to the type of ration, the nutrient composition of broiler chicken diet is different so as to offer the most appropriate balance for each growth phase: the prestart (1-7 days), initial (8-21 days), growth (22-35 days) and final (36-42 days). Therefore the use of the most appropriate type of ration must be considered with respect to the different farm contexts, such as regional availability of raw material, the technology level adopted by the feed plants, plus the animal genetic strain and the local weather conditions. By this approach, the best cost-benefit formulation is flexible and there is not a single rule to follow for achieving good yield indices.

The main steps to processing cereals include disruption of the seed coat (removal of the outer protective layers; the shells); exposure of the endosperm; reduction of particle size; agglomeration; mixing; heat treatment; pressure; changes in the structure of starch, and the addition of protein and fat (Thomas et al., 1998). The starch in cereals is in granule form, being highly organized complex resistant to the ingress of water and to the action of enzymes (Joy et al., 1997). Nevertheless, when heated above $100^{\circ} \mathrm{C}$ in the presence of water the process of gelatinization occurs, which consists in the swelling of granules to temperatures at which a break occurs, with destruction of the molecular order, and with irreversible changes in its properties (Thomas et al., 1998; Donald 2001; Kishida et al., 2001; Fukuoka 2002; Perez \& OlivaTeles, 2002).

Grain milling is a process which reduces the ingredient size by impact force, cutting or abrasion. This reduction increases both the number of particles as surface area, facilitating the handling and mixing of ingredients. The screening determines the particle size, and the process efficiency varies according to the grain type and machinery used (Koch 1996; Rodgers et al., 2012). For this process, two types of equipment are used: the hammer mill and the roller mill. The hammer mill has a set of hammers at high speed motion which press the particles through a screen. The roller mill consists of one or more pairs of horizontal rollers and the distance between them can vary according to the desired particle size. Efficiency of the process depends mainly on the type of grain, on the moisture contained therein, on the desirable particle size and on the engine power. As described by Koch (1996), in the hammer mill the particles generally have a spherical shape with a large size variation and, in the roller mill the particles tend to be uniform in size, but irregularly shaped, and require less electricity. Different types of grain milled under similar conditions can result in grains of different sizes (Lentle et al., 2006; Amerah et al., 2007; Amerah et al., 2008). Thus, it is suggested different screen sizes be used, according to the type of grain, in order to obtain the desired particle size (Amerah et al., 2007). The data provided by Nir et al. (1990) show that the productive yield of broilers is not influenced by the grinding process when the particle size is the same. Meanwhile, Nir et al. (1995) found greater weight gain in the use of particles by roller mill, because of the larger particle size and better uniformity of feed. Pelletization can be defined as a process of clustering of milled particles of an ingredient (or a mixture of ingredients), through mechanical processes and in combination with moisture, heat and pressure. The use of thermally processed ration can create a differential in the production of broiler chickens, especially in the pre-start phase. Chicks fed with crumbled diets have greater weight gain and better feed conversion than those fed with mash ones, despite this effect not always being observed until they are 42 days old. It is recommended that pre-starter feed be provided in crumble form, since this promotes nutritional benefits into the first weeks of rearing at an acceptable cost of production (Silva et al., 2004).

Birds are able to select different sizes of feed particles very early on life. The format and structure of the beak 
determines the size and type of food to be ingested, and thus the granulometry of the particle is of high importance for the regulation of the consumption. Granulometry is defined as a measure of feed particle size. According to the standard adopted in recent years (ASAE, 1983), the average particle size is given by the geometric mean diameter (GMD) of a representative sample, expressed in millimetres $(\mathrm{mm})$ or microns $(\mu \mathrm{m})$ and its variation is described as the geometric standard deviation (GSD). The higher the GSD, the more uneven is the feed particle size. It is common for substantial variation to occur in the particle size $(630-1450 \mu \mathrm{m}$, according to Addo et al. (2012) and, therefore, routine monitoring is desirable in the manufacturing process to maintain the quality of the final product in terms of GMD and GSD. As suggested by Nir et al. (1994a), the uniformity of feed particles is considered important for good performance for broiler fed mash ration, since the birds spend less time searching and selecting the larger particles.

It is well documented that the particle size after grinding in broiler feed is most critical in mash diets compared to pellet and crumbled (Hamilton \& Proudfoot, 1995; Nir et al., 1995; Svihus et al., 2004; Péron et al., 2005; Amerah et al., 2007). Furthermore, the pre-starter diets must be formulated with ingredients of better quality to meet the requirements of the initial stage (Lilburn, 1998), since the birds quickly respond to the stimulus of food intake immediately after hatching (Vieira \& Pophal, 2000; Noy \& Sklan, 2002). Several studies suggest that chickens at all ages show a preference for larger particles and this fact is marked with increasing age, probably due to the development of both digestive and buccal apparatus (Nir et al., 1990; Nir et al., 1994b). Thus, the increase in granulometry increases body weight at slaughter age and thus the economic feasibility (Hamilton \& Proudfoot, 1995), but Parsons, et al. (2006) found a drop in performance when the size is greater than $1.042 \mu \mathrm{m}$. It has been suggested that chicks prefer the particles of 700-900 $\mu \mathrm{m}$ (Douglas et al., 1990; Nir et al., 1990; Nir et al., 1994b; Nir et al., 1995) or 600-900 um (Amerah et al., 2007), while Portella et al., (1988), suggest a particle larger than $1180 \mu \mathrm{m}$, and for adult birds greater than $2360 \mu \mathrm{m}$.

Nir et al. (1994b) observed higher consumption in mash diets with particles of $769 \mu \mathrm{m}$ for broilers at prestarter phase (1-7 days old) when compared with GMD of $525 \mu \mathrm{m}$ and $1260 \mu \mathrm{m}$. This result may be related to the lower GSD (1630) in relation to other considered sizes (2.000). These findings are in agreement with
Amerah et al. (2008) and are also reported by Lott et al. (1992), who found higher body weight and better feed conversion in broilers fed with $716 \mu \mathrm{m}$ of DGM up to 21 days of age. On the other hand, no differences were seen in the crumbled diet with 690 and $974 \mu \mathrm{m}$ of GMD.

The feeding of chickens with whole grains has been associated with an improvement in gut development and health due to the stimulation of the gizzard (Hetland et al., 2002; Gabriel et al., 2006) and also with a lower incidence of proventricular dilatation (Jones \& Taylor, 2001). The gizzard is an organ that plays a key role in the diet of domestic chickens, aiding digestion in both the reduction of particle size through mechanical grinding of the feed, as in the chemical degradation of nutrients, in addition to regulating the feed flow (Hetland et al., 2004). The contents of the gizzard are dumped when the particle size is reduced by $15-40 \mu \mathrm{m}$ (Hetland \& Svihus, 2001). Recent and past publications suggest that at least $20-30 \%$ of the particles should present a size greater than $1000 \mu \mathrm{m}$ (Svihus, 2011) or 1500-2000 $\mu \mathrm{m}$ (Nir et al., 1994a), because finely ground particles can inhibit the functioning of the gizzard. In line with these reports, the findings of López \& Baião (2004) suggest that a coarser texture contributes to the performance of broilers fed with mash; crumbled and expanded crumbled diets are favored mainly for carcass yield and the weight of digestive organs, but the intake was the same for mash diets with different GMD. Conversely, Dahlke et al. (2001) reported a decrease in consumption and weight gain with rations of smaller particle size, in addition to a worsening in feed conversion with pelleted diet processed from particles with smaller GMD.

In the initial growth stage, generally mash or crumble diet is offered because the birds at this stage are still unable to ingest pellets and do not regulate feed intake according to the energy level (Faria et al., 2006). The physical form of pre-start diet (1-7 days) influences the performance of broilers until the end of the initial phase (8-21 days old), but the effects diminish until slaughter age with no effect on carcass characteristics (Freitas et al., 2009). Several studies are in line with the increase of broiler performance when processed diets are offered, which is mostly explained both by improvements in weight gain and feed conversion (Jones et al., 1995; Scott et al., 1997; Leeson et al., 1999; Lecznieski et al., 2001; Vargas et al., 2001; Greenwood et al., 2004; Silva et al., 2004; Maiorka et al., 2005; Lara et al., 2008); development of the digestive tract (Shamoto \& Yamauchi, 2000; 
Engberg et al., 2002; Dahlke et al., 2003; Zang et al., 2009); increasing of feed density leading both to nutrient intake and to growth rate (Engberg et al., 2002; McKinney \& Teeter 2004; Lemme et al., 2006; Freitas et al., 2008; Meurer et al., 2008; Freitas et al., 2009); greater nutrient digestibility (Moreira et al., 1994; Vargas et al., 2001; Goodband et al., 2002; Freitas et al., 2008; Zang et al., 2009); reduction on particles selectivity by the birds and better palatability (Gadzirayi et al., 2006; Lara et al., 2008); minimization of energy expenditure during feeding (Nir, et al., 1994c; Leeson et al., 1999; Jensen, 2000; López et al., 2007); decreasing of wastage (Jensen, 2000; Gadzirayi et al., 2006); facilitating the production-logistics at feed plants, as many as on farms (Nir et al., 1995; Plavnik \& Sklan, 1995; Vargas et al., 2001; McKinney \& Teeter, 2004; Greenwood et al., 2004) and; better cost benefit ratio in relation to mash diets (Axe 1995; Dozier III 2001; Meinerz et al., 2001; Vargas et al., 2001; Engberg et al., 2002; Fairfield 2003; López \& Baião, 2004; McKinney \& Teeter, 2004; Corzo et al., 2011; Oliveira et al., 2011).

Pelleting is the key factor in the profitability of a feed plant. Although there are several benefits of pelleted diet on broiler performance, factories should focus on cost-benefit ratio. For integrated systems, improved feed conversion should pay the cost of the process (Fairfield, 2003). Pelleting also facilitates production-logistics adopted in both feed plants and farms. This is done mainly by minimizing contamination of the feed by reducing the microbial population during processing, which decreases the selectivity by birds avoiding a nutritional imbalance, promotes improvement in the feed flow at feeders, favours the storage and transportation by a greater quantity in less physical space and minimizes the formation of fines (Vargas et al., 2001). Fines are considered those particles that disintegrate from the initial structure of the pellet.

Waste reduction by using pelleted diet can reach $18 \%$ in relation to mash type, according to the findings reported by Gadzirayi et al. (2006), due to increased particle aggregation and decreased selection of most preferred ingredients by birds. As previously mentioned, pelleted diets aid in the development of the digestive tract, but Meurer et al. (2008) pointed out that when both mash and pelleted diets are equalized, the weight gain is equalized, as well. Another issue regarding chickens fed pelleted diets is the reduction of time spent for the consummatory act. Given this, birds increase their resting time, which favours lower energy expenditure in maintaining and increasing availability of net energy for production (Nir et al., 1994c; Leeson et al., 1999; Skinner-Noble et al., 2005; López et al., 2007; Lara et al., 2008). Furthermore, the average time spent at the feeder depends on the physical form of the feed, which could range from $56 \mathrm{~s}$ in pelleted feed and $114 \mathrm{~s}$ in mash physical form (Yo et al., 1997). Thus, the duration of poultry meals can influence flock performance, since the increasing feeding time brings on disadvantages for submissive birds that probably will not consume their nutritional requirements for optimal development (Ferket \& Gernat, 2006).

On the other hand, some drawbacks of pelleted diets have also been pointed out. Among them can be highlighted a higher accumulation of abdominal fat and increase of the mortality rate in relation to mash diet (Lecznieski et al., 2001). The probable reason for this is that birds fed pelleted rations remain inactive longer than active, i.e. stay lying longer than walking (Nir et al., 1995; López \& Baião, 2004). Moreover, pelleted diet can increase the susceptibility of birds to death by ascites and sudden death syndrome (Garcia Neto \& Campos, 2002; Arce-Menocal et al., 2009), this phenomenon being more pronounced in males than in females (Nir et al., 1995). This could be attributed to the reduced number of meals, resulting in a higher intestinal load associated with a faster rate of food transit and greater amount of chime in the intestine, which increases the need for oxygen in the small intestine. Furthermore, increased locomotor disorders (lameness) have been reported with the use of pelleted compared to mash diet (Brickett et al., 2007), in addition to difficulties in maintaining good quality of pellets (Meurer et al., 2008).

An expression used to refer to the quality of the pellet is Pellet Durability Index (PDI, given in \%) and nowadays the most widely used method to determine it (ASAE 2003a; ASAE 2003b). Cutlip et al. (2008) reported that the best quality pellets (PDI, 90 versus $80 \%$ ) produce a lower feed conversion and higher yield of breast meat. An improvement of only $4 \%$ in PDI can contribute significantly to the performance of broilers. Likewise, Moritz et al. (2001) suggest that the pellets of high quality (PDI; $87 \%$ ) improve feed efficiency compared with lower quality (IDP, 62\%). Some recent studies indicate that the supply of a lower quality pelleted diet, with the addition of 20 to $35 \%$ of milled maize in both growing and final phase of rearing, can promote a better cost-benefit, since performance and meat yield are similar to those birds that are fed only with high-quality pellet (Clark et al., 2009; Dozier III et al., 2009; Dozier III et al., 2010). 
The pellets are considered fragile material (Aarseth \& Prestløkken, 2003) and their disruption occurs during manufacture, distribution and final delivery to animals on the farm. It is believed that the pneumatic transport at both plant and farm is the main cause of these disruptions (Thomas \& Van Der Poel, 1996). Different birds in different parts of the shed can receive different levels of fines and pellets, which will affect the growth rate and uniformity of the flock. The proportion of fines of a ration depends on various factors, such as the types of ingredients, the use of binders, the matrix conditions used in pelleting, amount of moisture, pressure and steam levels and handling. Briggs et al. (1999) define a pellet quality as the ability of a pellet to remain intact during handling, supported by Angulo et al. (1996) who pointed out that the quality is inversely proportional to the size of feed particles; i.e. the smaller the particle size, the greater the surface for absorbing moisture from steam, leading to a better lubrication mixture and, thereby, a better pellet quality. So the processing of pellets with coarse feed particles results in break points and, consequently, produces more fines (Behnke, 2001). Other studies, on the other hand, have reported that the pellets made from different particle sizes do not influence broiler performance (Svihus et al., 2004; Péron et al., 2005). The use of pressure to alter the feed physicochemical properties in combination with water and heat, and the use of pressure to pre-densify the mash feed before pelleting, are key factors for obtaining a pellet with good quality (Thomas et al., 1997).

The quality of the pellets may be the subject of strong disagreement between researchers, and feed manufacturers due to their high effect on animal performance and consequently the cost-benefit ratio in feed processing. The high concentration of fines can annul the benefits of a pelleted feed, increasing the cost and making the process unfeasible to the industry, since the benefits of this process practically disappeared in comparison to the mash feed (McKinney \& Teeter, 2004; Meurer et al., 2008). According to Behnke (1996), the factors that most affect pellet quality in a conventional pelleting system are the formulation $(40 \%)$, conditioning $(20 \%)$, particle size $(20 \%)$, die specification (15\%) and cooling (5\%). The high-quality pellets provide higher carcass weight (Lilly et al., 2011), increase broiler growth by $25 \%$ and increase average feed consumption, compared to low quality and mash diet rich in proteins (McKinney \& Teeter, 2004). Interestingly, the mash diets indicate a higher feed intake with a similar weight gain to low-quality pellets, suggesting, in this sense, a better digestibility of low-quality pelleted than mash diet (Lemme et al., 2006). Also, the findings reported by Carré et al. (2005) indicate a positive correlation between the pellet durability and feed efficiency. The increase in fines in the diet reduces consumption and weight gain in broiler chickens, and, interestingly, the findings of Quentin et al. (2004) agree that this drop is five times higher for genetic selection for rapid growth compared with the slow growth strain. This could imply that these birds exhibit greater sensitivity to feed form, probably due to a limitation both in adaptability and foraging behaviour.

The relative growth rate of the chicks increases approximately 3\% per day during the first days of life to $20 \%$ per day for five days old and remains at this rate for fifteen days (Nir et al., 1993). Slightly different results from Sell (1996) indicate that the relative growth rate is approximately $12 \%$ during the first 4 days, with a gradual increase to a peak of $20 \%$ on the sixth day of age and diminishing thereafter. It is, therefore, clear that the feed quality plays a key role in achieving a good flock performance at slaughter time, with superior care at the initial phase. Although there are some negative consequences, it is clear that, in general, processed diets are more convenient than those non-processed (mash diets). However, more studies are needed on the preference of birds for a particular type of feed, which could lead to a better understanding of the feeding processes and then drive us to accurate decision making on feed plant, and thus achieve a better cost-benefit without compromising bird welfare.

\section{Design and management of feeders}

At the rearing environment, it is very important that the food sources (feeders and drinkers) are properly arranged and well managed. Several studies indicate that some design features, such as size, location, geometry, spacing and angle, can affect the behaviour of animals. Deployment of design strategies that weaken the agonistic interactions and produce feed wastage during the use of these devices by the animals is common (Buskirk et al., 2003; Wolter et al., 2009). The feed continuously provided for broiler is essential for them to express their genetic potential. The fodder also needs to be delivered in a clean, uniform, and easy to access way. For the initial phase, the tray-feeder type, the infantile-tube and/or the automatic, are used; the latter is generally used at all rearing phases. In addition to the automatic type, the tube type could be used for the intermediate and final phases (Englert, 1998). 
The feeders should be uniformly distributed on rearing area. In some models, a partition grid is provided over the feed trough, which function is to homogenize the distribution of birds, reducing competition and decreasing wastage when the birds are feeding. Neves et al. (2010) reported that broilers tend to spend more time at the feeders without a partition grid, and this can be explained by the ease of access to the feeding area. Although it cannot be claimed that the birds had a higher intake, the foraging behaviour related to environment exploration was more evident. On the other hand, this preference disfavors wastage issues, always undesirable to the farmer.

Poultry consumes the feed regularly throughout the day, but there is a subtle increase in the intake at the beginning and the end of the light period. In a continuous lighting program, the intake is constant, regardless of the time of day. The nature of the diet is considered the factor that most influences weight gain and feed conversion on broilers. It is essential that the feeding equipment provide ease of access. Although few studies are available, the effect of feeder height has been assessed and is recommended as good management by some guidebooks.

From 35 days, the feeder use should be as low as possible without allowing birds to eat while lying, because this can compromise the integrity of the breast due to corns, and deny access to other birds. It is recommended that the feedstuff layer be kept low within the trough so that particles adhering to the beak drop back into the trough, not onto the ground (Planalto, 2006; Roll et al., 2010b). Therefore, working with tube-type feeders is recommended, with the trough upper edge at bird breast level or lower, but not touching the ground, since movement is an important factor in feeding the flow toward the trough (Roll et al., 2010b). It has been reported that there is no difference in productivity rates (daily weight gain, feed conversion, mortality) as a function of the feeder height; however, at a lower height, the average body weight can be up to $7 \%$ higher (Quintana et al., 1998), with a lower percentage of intramuscular fat in the thighs and greater muscle in drumsticks (Roll et al., 2010b).

Another concern of farmers is that the feedstuff mixes with litter material, compromising the quality of the feed. The dust bathing is a natural behaviour of the birds, which is characterized by the act of rubbing on the ground and throwing litter material on the body using the legs and wings (Vestergaard et al., 1990), hence the material is more easily thrown into the troughs of lower height. However, it was not found to compromise the microbiological quality of feed (Roll et al., 2010b). It has also been suggested that feeders regulated too high can inhibit consumption of the smaller birds and thus contribute to the unevenness of the flock (Ferket \& Gernat, 2006). Considering bird preference, Roll et al. (2010a) found that broilers tend to consume more feed in feeders of lowest height. In this specific study, only $23 \%$ of the birds that fed initially at the low trough moved to the highest one, while $100 \%$ of those who at first chose the highest feeder changed to the lowest feeder. In addition, the feeders adjusted near the ground allow all birds, including the less developed, to feed themselves more easily. The authors also suggest that, on average, the birds pass twice the time consuming in the lowest feeder, and although the frequency of visits decreases, no significant difference was observed in feed intake. This situation indicates a negative correlation between the frequency of visits and the amount of ingested feed. With the course of time birds reduce the intensity of consumption probably by reducing the size of the mouthful and by being comfortable in the troughs of lower height.

On the other hand, in laying hens, more advantages were indicated by using higher feeders. In this situation, the birds adopt a posture that discourages other birds from trampling on their backs, thus promoting better conditions of plumage and reducing feather pecking and cannibalism (Freire et al., 1999). Other studies assessing nipple-type drinkers suggest that the increase in height relative to the ground reduces the water consumption in broilers (May et al., 1997; Lott et al., 2001), especially because water intake in this model is not a natural behaviour and because the stretching of the neck is greater, particularly when the animals are puffed, creating a detrimental effect on weight gain, feed conversion, and increasing mortality (Lott et al., 2001; Ipek et al., 2002).

Although many reports recommend height adjustment of the feeders, e.g. back height (Ávila et al., 1992; Agroceres, 2004; Ávila et al., 2006; Aviagen, 2009; Cobb-Vantress, 2010; Albino et al., 2011); crop height (Planalto, 2006); and breast height (Bassi et al., 2006; GloboAves, 2011). Roll et al. (2010b) point out, however, some practical reasons to believe that these recommendations may not be ideal for the rational management of broiler chickens: 1) the time spent by the producer to carry out this practice; 2 ) the feeders which are adjusted to the birds' back height might hamper the ingestion because the birds, in their natural environment, seek and ingest food directly from the ground; 3 ) the feeders with a very high setting require 
more effort to achieve feed, in addition to the need for a higher layer of feedstuff in the trough to facilitate ingestion, which increases wastage; 4) aviaries with very high layers of litter (above $8.0 \mathrm{~cm}$ ), with advancing age experience a lowering of these layers, leading to an increased distance from the ground to the feeder, which can hamper access to feed for smaller birds; 5) lack of scientific publications justifying the adoption of this practice.

\section{FINAL REMARKS}

The benefits of the processed feed in broiler chicken performance is well documented, and, despite the high cost of production, the pelleted diet, even with a lower quality (durability index), has more advantages than the mash type. However, the feasibility of feed manufacturing may vary in different regions according to the availability of raw material and the technology adopted by the feed plants. So far, most research on the poultry feeding behaviour addresses the productivity indices and bird physiological responses, but few studies have considered the biomechanical characteristics involved in this process.

A better understanding of the mechanical process of the bird jaw apparatus during feeding might be an effective method for determining the relationship between different types of ration in biomechanical patterns, and for considering the anatomical variations between different strains, ages and genders, and also the impact of feeder design. In this sense, the high speed camera combined with techniques of computational image analysis is a remarkable technology to aid these assessments. Some behavioural patterns that happen in a very short period of time cannot be detected by conventional cameras. Furthermore, it is a non-invasive technique for evaluating animal behaviour and allows natural body movement.

\section{ACKNOWLEDGEMENTS}

The first author wish to thank CNPq - National Council for Scientific and Technological Development for the scholarship.

\section{REFERENCES}

Aarseth KA, Prestløkken E. Mechanical properties of feed pallets: Weibull analysis. Biosystems Engineering 2003; 3: 349-361.

Abourachid A, Hackert R, Herbin M, Libourel PA. Lambert, F.; Gioanni, H.; Provini, P.; Blazevic, P.; Hugel, V. Bird terrestrial locomotion as revealed by 3D kinematics. Zoology 2011; 114: 360-368.
Addo A, Bart-Plange A, Akowuah JO. Particle size evaluation of feed ingredient produced in the Kumasi Metropolis, Ghana. ARPN Journal of Agricultural and Biological Science 2012; 7(3): 177-181.

Agroceres, 2004. Manual de Manejo de Frangos Agrosseres, s.l.: AGROSSERES ROSS

AlbinoJJ, Bassi L, SaatkampM. 2011. Regulagemedistribuição decomedouros tubulares e bebedouros pendulares em aviários convencionais. [Online] Available at: ALBINO, J. J.; BASSI, L.; SAATKAMP, M. Regulagem e distribuição de comedouros tubulares e bebedouros pendulares em aviários convencionais. Erhttp://pt.engormix.com/MA-avicultura/ad [Acessed: 14 August 2012]

Amerah A M, Ravindran V, Lentle RG, Thomas DG. Feed particle size: Implications on the digestion and performance of poultry. World's Poultry Science Journal 2007; 63: 439-451.

Amerah AM, Ravindran $V$, Lentle RG, Thomas DG. Influence of feed particle size on the performance, energy utilization, digestive tract development, and digesta parameters of broiler starters fed wheatand corn-based diets. Poultry Science 2008; 87: 2320-2328.

Angulo E, Brufau J, Esteve-Garcia E. Effect of a sepiolite product on pellet durability in pig diets differing in particle size and in broiler starter and finisher diets. Animal Feed Science Technology 1996; 63: 25-34.

Arampatzis A, Brüggemann G, Metzler V. The effect of speed on leg stiffness and joint kinetics in human running. Journal of Biomechanics 1999; 32: 1349-1353

Arce-Menocal J, Avila-Gonzales E, Lopez-Coelho C, Garibay-Torres L, Martinez-Lemus LA. Body weight, feed-particle size, and ascites incidence revisited. The Journal of Applied Poultry Research 2009; 18 : 465-471.

ASAE - American Society of Agricultural Engineers, 1983. Wafers, pellets, crumbles-definitions and methods for determining density, durability, and moisture content, St. Joseph: American Society of Agricultural Engineers.

ASAE - American Society of Agricultural Engineers, 2003a. Cubes, pellets, and crumbles - definitions and methods for determining density, durability and moisture content, St. Joseph: ASABE.

ASAE - American Society of Agricultural Engineers, 2003b. Method of determining and expressing fineness of feed materials by sieving, St. Joseph: ASABE.

Aviagen, 2009. Ross Broiler Management Manual, s.I.: s.n.

Ávila VS, Jaenisch FRF, Pieniz LC, Ledur MC, Albino LFT, Oliveira PAV. Produção e manejo de frangos de corte, Concórdia: Embrapa Suínos e Aves, 1992

Ávila VS, Kunz A, Bellaver CP, Paiva D, Jaenisch FRF, Mazzuco H, Trevisol IM, Palhares JCP, Abreu PG, Rosa PS. Boas Práticas de Produção de Frangos de Corte. Concórdia: Embrapa Suínos e Aves. 2006.

Axe DE. Factors affecting uniformity of a mix. Animal Feed Science and Technology 1995; 53: 211-220.

Bakker PP, Manske SL, Ebacher V, Oxland TR. Cripton PA, Guy P. During sideways falls proximal femur fractures initiate in the superolateral cortex: Evidence from high-speed video of simulated fractures. Journal of Biomechanics 2009; 42: 1917-1925.

Bassi LJ, Albino JJ, Ávila VS, Shmidt GS, Jaenisch FRF. Recomendações Básicas para Manejo de Frangos de Corte Colonial, Concórdia: S.n., 2006

Beare JE, Morehouse JR, DeVries WH, Enzmann GU, Burke DA, Mag-nuson DSK, Whittemore SR. Gait analysis in normal and spinal contused mice using the treadscan system. Journal of Neurotrauma 2009; 26: 20452056 . 
Behnke KC. Feed manufacturing technology: current issues and challenges. Animal Feed Science and Technology 1996; 62(1): 49-57.

Behnke KC. Factors influencing pellet quality. Feed Technology 2001; 5(4): $9-22$

Berdoy M. Defining bouts of behaviour: a three process model. Animal Behaviour 1993; 46: 387-396.

Bergmann G, Deuretzbacher G, Heller M, Graichen F, Rohlmann A, Strauss J, Duda GN. Hip contact forces and gait patterns from routine activities. Journal of Biomechanics 2001; 34: 859-871.

Bermejo R, Allan RW, Houben D, Deich JD, Zeigler HP. Prehension in the pigeon I: descriptive analysis. Experimental Brain Research 1989; 75: 569-576

Bock WJ.. Kinetics of the avian skull. Journal of Morphology 1964; 114 : $1-42$.

Bout RG, Zweers GA. The role of cranial kinesis in birds. Comparative Biochemistry and Physiology 2001; 131A: 197-205.

Bracha V, Nilaweera W, Zenitsky G, Irwin K. Video recording system for the measurement of eyelid movement during classical conditioning of the eyeblink response in the rabbit. Journal of Neuroscience Methods 2003; 125: 173-181.

Brickett KE, Dahiya JP, Classen HL, Annett CB, Gomis S. The Impact of Nutrient Density, Feed Form, and Photoperiod on the Walking Ability and Skeletal Quality of Broiler Chickens. Poultry Science 2007; 86: 2117-2125

Briggs JL, Maier DE, Watkins BA, Behnke KC. Effect of ingredients and processing parameters on pellet quality. Poultry Science 1999; 78: 1464-1471.

Buskirk DD, Zanella AJ, Harrigan TM, Van Lente JL, Gnagey LM, Kaercher MJ. Large round bale design affects hay utilization and beef cow behavior. Journal of Animal Science 2003; 81: 109-115

Carré B, Muley N, Gomez J, Oury F-X, Laffitte E, Guillou D, Signoret C. Soft wheat instead of hard wheat in pelleted diets results in high starch digestibility in broiler chickens. British Poultry Science 2005; 46 (1): 66-74.

Clark PM, Behnke KC, Fahrenholz AC. Effects of feeding cracked corn and concentrate protein pellets on broiler growth performance. The Journal of Applied Poultry Research 2009; 18: 259-268.

Cobb-Vantress. COBB Broiler Management Guide, s.I.: COBB-VANTRESS, 2010.

Corzo A, Mejia L, Loar II RE. Effect of pellet quality on various broiler production parameters. The Journal of Applied Poultry Research 2011; 20: 68-74.

Cutlip SE, Hott JM, Buchanan NP, Rack AL, Latshaw JD, Moritz JS. The Effect of Steam-Conditioning Practices on Pellet Quality and Growing Broiler Nutritional Value. The Journal of World's Poultry Research 2008; 17 : 249-261

Dahlke F, Ribeiro AML, Kessler AM, Lima ARR, Maiorka A. Effect of corn particle and physical form of the diet on the gastrointestinal structures of broiler chickens. Brazilian Journal of Poultry Science 2003; 5: 61-67.

Dahlke F, Ribeiro AML, Kessler AM, Lima AR. Corn particle size and physical form of the diet and their effects on performance and carcass yield of broilers. Brazilian Journal of Poultry Science 2001; 4(3): 241-248.

Dangles O, Ory N, Steinmann T, Christides JP, Casas J. Spider's attack versus cricket's escape: velocity modes determine success. Animal Behaviour 2006; 72: 603-610.
Dawson MM, Metzger KA, Baier DB, Brainerd EL. Kinematics of quadrant bone during feeding in mallard ducks. The Journal of Experimental Biology 2011; 214: 2036-2046.

Deban SM, O'Reilly JC. The ontogeny of feeding kinematics in a giant sala-mander ryptobranchus alleganiensis: Does current function or phylogenetic relatedness predict the scaling patterns of movement? Zoology 2005; 108: 155-167.

Domenici P, Blake RW. Biomechanics in animal behaviour. 1 ed. Oxford: BIOS Scientific Publishers Ltd.

Donald AM. Plasticization and self-assembly in the starch granule. Cereal Chemistry 2001; 78: 307-314.

Douglas JH, Sullivan TW, Bond PL, Struwe FJ, Baier JG, Robeson LG. Influence of grinding, rolling, and pelleting on the nutritional value of grain sorghums and yellow corn for broilers. Poultry Science 1990; 69: 2150-2156.

Dozier III W. Cost-effective pellet quality for meat birds. Feed Management, February, 2001; 52(2), p. 3

Dozier III WA, Behnke KC, Gehring CK, Branton SL. Effects of feed form on growth performance and processing yields of broiler chickens during a 42-day production period. The Journal of Applied Poultry Research 2010; 19: 219-226

Dozier III WA, Behnke K, Twining P, Branton SL. Effects of the addition of roller mill ground corn to pelleted feed during a fifty-six-day production period on growth performance and processing yields of broiler chickens. The Journal of Applied Poultry Research 2009; 18: 310-317.

Emmans G, Kyriazakis I. Consequences of gentic change in farm animals on food intake and feeding behaviour. 2001; s.l., s.n., 115-125.

Engberg RM, Hedemann MS, Jensen BB. The influence of grinding and pelleting of feed on the microbial composition and activity in the digestive tract of broiler chickens. British Poultry Science 2002; 44 569-579.

Englert S. Avicultura: Tudo sobre raças, manejo e alimentação. 7 ed. Guaíba (Rio Grande do Sul): Editora Agropecuária, 1998.

Estrella SM, Masero JA. The use of distal rhyncokinesis by birds feeding in water. The Journal of Experimental Biology 2007; 210: 3757-3762.

Fairfield DA. Pelleting for Profit - Part 1. Feed and Feeding Digest 2003; 54(6): $1-5$

FAO, 2010. Poultry meet \& eggs., Rome: FAO.

FAO, 2012. Food Outlook, Rome: Trade and Market Division of FAO.

Faria DE, Faria Filho DE, Junqueira OM, Araújo LF, Torres KAA. Forma física e níveis de energia metabolizável a ração para frangos de corte de 1 a 21 dias de idade. ARS VETERINARIA - Revista de Medicina Veterinaria e Zootecnia 2006; 22(3): 259-264.

Feduccia A. 1986. Osteologia das aves. In: Anatomia dos animais domésticos. 5 ed. Rio de Janeiro: Guanabara Koogan, 1680-1689; 1986.

Ferket PR, Gernat AG. Factors that affect feed intake of meat birds: A Review. International Journal of Poultry Science 2006; 5(10): 905-911.

Freire R, Walker A, Nicol CJ. The relationship between trough height, feather cover and behaviour of laying hens in modified cages. Applied Animal Behaviour Science 1999; 63: 55-64.

Freitas ER, Sakomura NK, Dahlke F, Santos FR, Barbosa NAA. Desempenho, eficiência de utilização dos nutrientes e estrutura do trato digestório de pintos de corte alimentados na fase pré-inicial com rações de diferentes formas físicas. Revista Brasileira de Zootecnia 2008; 37: 73-78. 
Freitas ER, Sakomura NK, Vieira RO, Neme R, Traldi AB. Uso de diferentes formas físicas e quantidades de ração pré-inicial para frangos de corte. Revista Ciência Agronômica 2009; 40(2): 293-300.

Fukuoka M, Ohta KI, Watanabe H. Determination of the terminal extent of starch gelatinization in a limited water system by DSC. Journal of Food Engineering 2002; 53: 39-42.

Fuller PO, Higham TE, Clark, AJ. Posture, speed, and habitat structure: three-dimensional hindlimb kinematics of two species of padless geckos. Zoology 2011; 114: 104-112.

Fu SC, Chan KM, Chan LS, Fong, DTP, Lui PYP. The use of motion analysis to measure pain-related behaviour in a rat model of degenerative tendon injuries. Journal of Neuroscience Methods 2009; 179: 309-318.

Gabriel I, Mallet S, Leconte M, Fort G, Naciri M. Effects of whole wheat feeding on the development of coccidial infection in broiler chickens until market-age. Animal Feed Science and Technology 2006; 129: 279-303.

Gadzirayi CT, Mutandwa E, Chihiya J, Mlambo R. A comparative economic analysis of mash and pelleted feed in broiler production under deep litter housing system. International Journal of Poultry Science 2006; 7: 629-631.

Garcia Neto M, Campos EJ. Incidência de ascite em frangos de corte alimentados com rações comerciais de alto nível energético. Pesquisa Agropecuária Brasileira 2002; 37: 1205-1212.

GLOBOAVES, 2011. Manual de Manejo Linha Colonial, s.I.: s.n.

Goodband RD, Tokach MD, Nelssen JL. The effects of diet particle size on animal performance., Kansas: MF-2050 Feed Manufacturing. 2002

Greenwood MW, Cramer KR. Clark PM, Behnke KC, Beyer RS. Influence of feed form on dietary lysine and energy intake and utilization of broilers from 14 to 30 days of age. International Journal of Poultry Sciences 2004; 3: 189-194.

Gurd DB. Filter-feeding dabbling ducks (Anas s) can actively select particles by size. Zoology 2006; 109: 120-126.

Gurd DB. Predicting resource partitioning and community organization of filter-feeding dabbling ducks from functional morphology. The American Naturalist 2007; 169: 334-343.

Gussekloo SWS, Bout RG. The kinematics of feeding and drinking in paleognathous birds in relation to cranial morphology. Journal of Experimental Biology 2005, 208: 3395-3407.

Gussekloo SWS, Vosselman MG, Bout RG. Three-dimensional kinematics of skeletal elements in avian prokinetic and rhynchokinetic skulls determined by Roentgen stereo-photogrammetry. Journal of Experimental Biology 2001, 204: 1735-1744.

Habegger ML, Motta PJ, Huber DR, Deban SM.. Feeding biomechanics in the Great Barracuda during ontogeny. Journal of Zoology 2010; 283: $63-72$.

Hall SJ. Basic Biomechanics. 3ª ed. Singapore: Mcgraw-Hill; 1999

Hamilton RMG, Proudfoot FG. Ingredient particle size and feed texture effects on the performance of broiler chickens. Animal Feed Science and Technology 1995; 51: 203-210.

Herbin M, Hackert R, Gasc JP, Renous S. Gait parameters of treadmill versus overground locomotion in mouse. Behavioural Brain Research Journal 2007: 181: 173-179.

Herrel A, O'Reilly JC. Ontogenetic scaling of bite force in lizards and turtles. Physiological and Biochemical Zoology 2006; 79: 31-42.
Herrel A, Van Wassenbergh S, Wouters S, Aerts P, Adriaens D. A functional morphological aroach to the scaling of the feeding system in the African catfish, Clarias gariepinus. The Journal of Experimental Biology 2005; 208: 2091-2102

Hetland H, Choct M, Svihus B. Role of insoluble non-starch polysaccharides in poultry nutrition. World's Poultry Science Journal 2004; 60: 415-422.

Hetland $\mathrm{H}$, Svihus B. Effect of oat hulls on performance, gut capacity and feed passage time in broiler chickens. British Poultry Science 2001; 42: 345-361.

Hetland $H$, Svihus B, Olaisen V. Effect of feeding whole cereals on performance, starch digestibility and duodenal particle size distribution in broiler chickens. British Poultry Science 2002; 43(3): 416-423.

Huber DR, Claes JM, Mallefet J, Herrel A. Is extreme bite performance associated with extreme morphologies in sharks?. Physiological and Biochemical Zoology 2009; 82: 20-28.

Huber DR, Dean MN, Summers AP. Hard prey, soft jaws and the ontogeny of feeding mechanics in the spotted ratfish Hydrolagus colliei. Journal of the Royal Society Interface 2008; 5: 1-12.

Imura A, lino Y, Kojima T. Biomechanics of the continuity and speed change during one revolution of the Fouette turn. Human Movement Science 2008; 27: 903-913

Ipek A, Sahan U, Yilmaz B. The effect of drinker type and drinker height on the performance of broiler cockerels. Czech Journal of Animal Science 2002; 47(11) : 460-466

Jensen LS. Influence of pelleting on the nutritional needs of poultry. AsianAustralasian Journal of Animal Science 2000; 13: 35-46.

Jones F.T, Anderson KE, Ferket PR. Effect of extrusion on feed characteristics and broiler chicken performance. The Journal of Applied Poultry Research 1995; 4: 300-309.

Jones GPD, Taylor RD. The incorporation of whole grain into pelleted broiler chicken diets: Production and physiological responses. British Poultry Science 2001; 42: 477-483.

Joy MT, DePeters EJ, Gadel JG, Zinn RA. Effect of corn processing on the site and extent of digestion in lactating cows. Journal of Dairy Science 1997; 80: 2087-2097

King AS. Introdução às aves. In: Anatomia dos animais domésticos. 5 ed. Rio de Janeiro: Guanabara Koogan, 1677-1679; 1986.

Kishida T, Nogami H, Himeno S, Ebihara K. Heat moisture treatment of high amylose corn starch increases its resistant starch content but not its physiological effects in rats. Journal of Nutrition 2001; 131: 27162721

Koch K. Hammermills and rollermills, Kansas: MF-2048 Feed Manufacturing, 1996.

Korff WL, Wainwright PC. Motor pattern control for increasing crushing force in the striped burrfish (Chilomycterus schoepfi). Zoology 2004; 107: 335-346.

Lara LJC, Baião NC, Rocha JSR, Lana AMQ, Cançado SV, Fontes DO, Leite RS. Influência da forma física da ração e da linhagem sobre o desempenho e rendimento decortes de frangos de corte. Arquivo Brasileiro de Medicina Veterinária 2008; 60(4): 970-978.

Lecznieski JL, Ribeiro AML, Kessler AM, Penz Jr, AM. Influence of physical form and energy level of the diet on performance and carcass composition of broilers. Archivos Latinoamericanos de Produccion Animal 2001; 9(1): 6-11. 
Leeson S, Caston LJ, Summers JD, Lee KH.. Performance of male broilers to 70 days when feed diets of varying nutrient density as mash or pellets. The Journal of Applied Poultry Research 1999; 8: 452-464.

Lemme A, Wijtten PJA, Van Wichen J, Petri A, Langhout DJ. Responses of male growing broilers to increasing levels of balanced protein offered as coarse or pellets of varying quality. Poultry Science 2006; 85(04): 721-730.

Lentle RG, Ravindran V, Ravindran G, Thomas DV. Influence of feed particle size on the efficiency of broiler chickens fed wheat based diets. Journal of Poultry Science 2006; 43: 135-142.

Lilburn M.S. Pratical aspects of early nutrition for poultry. The Journal of Applied Poultry Research 1998; 7: 420-424.

Lilly KGS, Gehring CK, Beaman KR, Turk PJ, Sperow M, Moritz JS. Examining the relationships between pellet quality, broiler performance, and bird sex. The Journal of Applied Poultry Research 2011; 20: 231-239.

López CAA, Baião NC. Efeitos do tamanho da partícula e da forma física da ração sobre o desempenho, rendimento de carcaça e peso dos órgãos digestivos de frangos de corte. Arquivo Brasileiro de Medicina Veterinária 2004; 56(2): 214-221.

López CAA, Baião NC, Lara LJC, Rodriguez NM, Cançado SV. Efeitos da forma física da ração sobre a digestibilidade dos nutrientes e desempenho de frangos de corte. Arquivo Brasileiro de Medicina Veterinaria e Zootecnia 2007; 59(4): 1006-1013.

Lott BD, May JD, Simmons JD, Branton SL. The effect of nile height on broiler performaance. Poultry Science 2001; 80: 408-410.

Low J, Reed A. Basic biomechanics explained. Oxford: ButterworthHeinemann Ltd.; 1996.

Lu T, Chang C. Biomechanics of human movement and its clinical alications. Kaohsiung Journal of Medical Sciences 2012; 28: S13-S25.

Maiorka A, Dahlke F, Penz AM, Kessler AM.. Diets formulated on total or digestible amino acid basis with different energy levels and physical form on broiler performance. Brazilian Journal of Poultry Science 2005; 7(1): 7-50.

Mara KR, Motta PJ, Huber DR. Bite force and performance in the durophagous bonnethead shark, Sphyrna tiburo. Journal of Experimental Zoology 2009; 311A:1-11.

May JD, Lott BD, Simmons JD. Water consumption by broilers in high cyclic temperatures: bell versus nile waterers. Poultry Science 1997; 76: 944947.

McKinney L, Teeter R. Predicting effective caloric value of nonnutritive factors: I. pellet quality and II. prediction of consequential formulation dead zones. Poultry Science 2004; 83: 1165-1174.

Mclester J, Pierre PS. Applied Biomechanics: concepts and connections. Belmont: Thomson Wadsworth; 2008.

Meinerz C, Ribeiro AML, Penz Jr. AM, Kessler AM. Níveis de Energia e peletização no desempenho e rendimento de carcaça de frangos de corte com oferta alimentar equalizada. Revista Brasileira de Zootecnia 2001; 30 (6S): 2026-2032

Meurer RP, Fávero A, Dahlke F, Maiorka A. Avaliação de rações peletizadas para frangos de corte. Archives of Veterinary Science 2008; 13(3): 229240.

Moon RD, Zeigler HP. Food preferences in the pigeon (Columba livia). Physiology \& Behavior 1979; 22(6): 1171-1182.

Moreira I, Rostagno HS, Coelho DT, Costa PMA, Tafuri ML. Determinação dos coeficientes de digestibilidade, valores energéticos e índices de controle de qualidade do milho e soja integral processados a calor. Revista Brasileira de Zootecnia 1994; 23: 916-929.

Morita T, Fujiwara T, Negoro T, Kurata C, Maruo H, Kurita K, Goto S, Hirab $K$. Movement of the mandibular condyle and activity of the masseter and lateral pterygoid muscles during masticatory-like jaw movements induced by electrical stimulation of the cortical masticatory area of rabbits. Archives of Oral Biology 2008; 53: 462-477.

Moritz JS, Beyer RS, Wilson KJ, Cramer KR, McKinney LJ, Fairchild FJ. Effect of moisture addition at the mixer to a corn-soybean-based diet on broiler performance. The Journal of Applied Poultry Research 2001; 10: 347-353.

Neves DP, Nääs IA, Vercellino RA, Moura DJ. Do broilers prefer to eat from a certain type of feeder?. Revista Brasileira de Ciencia Avícola 2010; 12(3): 179-187

Nguyen QV, Park HC, Goo NS, Byun D. Characteristics of a Beetle's Free Flight and a Flaing-Wing System that Mimics Beetle Flight. Journal of Bionic Engineering 2010; 7: 77-86.

Nielsen BL. On the interpretation of feeding behaviour measures and the use of feeding rate as an indicator of social constraint. Applied Animal Behaviour Science 1999, 63: 79-91.

Nielsen BLLAB, Whittemore CT. Effects of single-space feeder design of feeding behaviour and performance of growing pigs. Animal Science 1995; 1 : 575-579.

Nir I, Hillel R, Ptichi I, Shefet G. Effect of particle size on performance .3. Grinding pelleting interactions. Poultry Science 1995; 74: 771-783.

Nir I, Hillel R, Shefet G, Nitsan Z. Effect of grain particle size on performance. 2. Grain texture interactions. Poultry Science 1994a; 73: 781-791.

Nir I, Melcion JP, Picard, M. Effect of particle size of sorghum grains on feed intake and performance of young broilers. Poultry Science 1990; 69: 2177-2184.

Nir I, Nitsan Z, Mahagna M. Comparative growth and development of the digestive organs and of some enzimes in broiler and egg type chicks after hatching. British Poultry Science 1993; 34: 523-532.

Nir I, Shefet G, Aaroni Y. Effect of particle size on performance. 1. Corn. Poultry Science 1994b; 73: 45-49.

Nir I, Twina Y, Grossman E, Nitsan Z. Quantitative effects of pelleting on performance, gastrointestinal tract and behavior of meat-type chickens. British Poultry Science 35: 589-601.

Noy $Y$, Sklan D. Nutrient use in chicks during the first week posthatch. Poultry Science 1994c; 81(03): 391-399.

Oliveira AA, Gomes AVC, Oliveira GR, Lima MF, Dias GEA, Agostino TSP, Sousa FDR, Lima CAR. Performance and carcass characteristics of broilers fed diets of different physical forms. Revista Brasileira de Zootecnia 2011; 40(11): 2450-2455.

Parsons AS, Buchanan NP, Blemings KP, Wilson ME, Moritz JS. Effect of Corn Particle Size and Pellet Texture on Broiler Performance in the Growing Phase. The Journal of Applied Poultry Research 2006; 15: 245-255.

Pennycuick CJ. Newton rules biology: A physical aroach to biological problems. New York: Oxford University Press, 1992.

Perez $\mathrm{H}$, Oliva-Teles A. Utilization of raw and gelatinized starch by European sea bass (Dicentrarchus labrax) juveniles. Aquaculture 2002; 205: 287 299.

Péron A, Bastianelli D, Oury FX, Gomez J, Carre B. Effects of food deprivation and particle size of ground wheat on digestibility of food components in broilers fed on a pelleted diet. British Poultry Science 2005; 46: 223-230. 
Picard M, Melcion JP, Bertrand D, Faure JM. Visual and tactile cues perceived by chickens. London, CAB Interational, 279-298; 2002.

PLANALTO G. Manual do Frango de Corte., s.I.: Granja Planalto, 2006.

Plavnik I, Sklan D. Nutritional effects of expansion and short time extrusion on feeds for broilers. Animal Feed Science and Technology 1995; 55: 247-251.

Portella FJ, Caston LJ, Leeson S. Aarent feed particle size preference by broilers. Canadian Journal of Animal Science 1988; 68: 923-930.

Quentin M, Bouvarel I, Picard M. Short- and long-term effects of feed form on fast- and slow-growing broilers. The Journal of Applied Poultry Research 2004; 13: 540-548.

Quintana JÁ, Castañeda MP, Aguilera H, López C, Quiroz M, Cázares R, Ruiz R, Ávila E. Efecto de la altura de los comederos sobre el largo del tarso, pigmentación y parámetros productivos en pollo de engorda. Veterinaria México 1998; 29(1): 41-47.

Rodgers NJ, Choct M, Hetland H, Sundby F, Svihus B. Extent and method of grinding of sorghum prior to inclusion in complete pelleted broiler chicken diets affects broiler gut development and performance. Animal Feed Science and Technology 2012; 171: 60-67.

Roll VFB, Dai Prá MA, Roll AAP, Xavier EG, Rossi P, Anciuti MA, Rutz F. Influência da altura de comedouros tubulares no comportamento ingestivo de frangos de corte (Effect of tubular feeder height on ingestive behavior of broiler). Archivos de Zootecnia 2010a; 59 (225): 115-122.

Roll VFB, Dai Prá MA, Xavier EG, Osório MT, Correa EK, Silveira MHD, Anciuti MA, Rutz F. Efeito da altura do comedouro tubular sobre o desempenho e qualidade de carcaça em frangos de corte no período de 28 a 42 dias de idade. Ciência Animal Brasileira 2010b; 11(4): 764769.

Sainsbury D. Poultry health and management. Saint Albans: Granada Publish Ltd., 1980.

Sakatani T, Isa T. PC-based high-speed video-oculography for measuring rapid eye movements in mice. Neuroscience Research 2004; 49: 123131.

Schaerlaeken V, Montuelle SJ, Aerts P, Herrel A. Jaw and hyolingual movements dur-ing prey transport in varanid lizards: effects of prey type. Zoology 2011; 114: 165-170.

Scott TA, Swift ML, Bedford MR. The influence of feed milling, enzyme sulementation, and nutrient regimen on broiler chick performance. The Journal of Applied Poultry Research 1997; 6: 391-398.

Sell J. Physiological limitations and potential for improvement in gastrointestinal tract function of poultry. The Journal of Applied Poultry Research 1996; 5: 96-101.

Serway RA, Jewett JW. Physics for scientists and engineers. 6 ed. Belmont: Brooks/Cole-Thomson Learning; 2004.

Shamoto K, Yamauchi, K. Recovery responses of chick intestinal villus morphology to different refeeding procedures. Poultry Science 2000; 79: 718-723.

Shan G. Biomechanical evaluation of bike power saver. Applied Ergonomics 2008; 39: 37-45

Silva JRL, Rabello CBV, Dutra Jr WM, Ludke MCMM, Barroso JF, Freitas CRG.; Campelo Filho EVB, Aquino LM. Efeito da forma física e do programa alimentar na fase préinicial sobre desempenho e características de carcaça de frangos de corte. Acta Scientiarum. Animal Sciences 2004; 26: 543-551
Skinner JT, Waldroup AL, Waldroup PW. Effects of dietary nutrient density on performance and carcass quality of broilers 42 to 49 days of age. The Journal of Applied Poultry Research 1992; 1: 367-372.

Skinner-Noble DO, McKinney LJ, Teeter RG. Predicting effective caloric value of nonnutritive factors: III. Feed form affects broiler performance by modifying behavior patterns. Poultry Science 2005, 84: 403-411.

Slater PJB. The temporal pattern of feeding in the Zebra finch. Animal Behaviour 1974; 22: 506-515.

Smith M, Yanega GM, Ruina A. Elastic instability model of rapid beak closure in hummingbirds. Journal of Theoretical Biology 2011; 282: 41-51.

Stansfield BW, Nicol AC, Paul JP, Kelly IG, Graichen F, Bergmann G. Direct comparison of calculated hip joint contact forces with those measured using instru-mented implants. An evaluation of a three-dimensional mathematical model of the lower limb. Journal of Biomechanics 2003; 36: 929-936.

Steeve RW. Babbling and chewing: jaw kinematics from 8 to 22 months. Journal of Phonetics 2010; 38: 445-458.

Stefen C, Ibe P, Fischer MS. Biplanar X-ray motion analysis of the lower jaw movement during incisor interaction and mastication in the beaver (Castor fiber L. 1758). Mammalian Biology 2011; 76: 534-539.

Svihus B. The gizzard: function, influence of diet structure and effects on nutrient availability. World's Poultry Science Journal 2011; 67: 207-223.

Svihus B, Klovstad KH, Perez V, Zimonja O, Sahlstrom S, Schuller RB. Physical and nutritional effects of pelleting of broiler chicken diets made from wheat ground to different coarsenesses by the use of roller mill and hammer mill. Animal Feed Science and Technology 2004; 117: 281 293.

Thomas M, Van Der Poel AFB. Physical quality of pelleted animal feed. 1 Criteria for pellet quality. Animal Feed Science and Technology 1996; 61: 89-112.

Thomas M, Van Vliet T, Van Der Poel AFB. Physical quality of pelleted animal feed 3. Contribution of feedstuff components. Animal Feed Science Technology 1998; 70: 59-78.

Thomas M, Van Zuilichem DJ, Van Der Poel AFB. Physical quality of pelleted animal feed. 2. contribution of processes and its conditions. Animal Feed Science Technology 1997, 64: 173-192.

Tran, HQ, Mehta RS, Wainwright PC. Effects oframspeedonpreycapturekinematicsofjuvenilelndo-Pacific tarpon, Megalops cyprinoides. Zoology 2010; 113: 75-84.

Truong TV, Le TQ, Byun D, Park HC, Kim M. Flexible wing kinematics of a free-flying beetle (Rhinoceros Beetle Trypoxylus Dichotomus). Journal of Bionic Engineering 2012; 9: 177-184.

USDA, 2012. Livestock and Poultry: World Markets and Trade, s.I.: USDA.

Van Den Heuvel WF. Kinetics of the skull in chicken (Gallus Gallus Domesticus). Netherlands Journal of Zoology 1992; 42(4): 561-582.

Van Der Heuvel WF, Berkhoudt H. Pecking in the chicken (Gallus Gallus Domesticus): Motion analysis and stereotypy. Netherlands Journal of Zoology 1998; 48(3): 273-303

Vargas GD, Brum PAR, Fialho FB, Rutz F, Bordin R.. Efeito da forma física da ração sobre desempenho de frangos de corte machos. Revista Brasileira de Agrociência 2001; 7(1): 42-45.

Vestergaard K, Hogan JA, Kruijt JP. The development of a behaviour system: Dustbathing in the Burmese red junglefowl I. The influence of the rearing environment on the organization of dustbathing. Behaviour 1990; 112(1): 35-52. 
Vieira SL, Pophal S. Post-hatching nutrition in broiler. Brazilian Journal of Poultry Science 2000; 02(03): 189-199.

Wainwright PC. Ecomorphology: experimental functional anatomy for ecological problems. American Zoologist 1991; 31: 680-693.

Westneat MW, Long Jr JH, Hoese W, Nowicki S. Kinematics of birdsong: functional correlation of cranial movements and acoustic features in sparrows. The Journal of Experimental Biology 1993; 182: 147-171.

Wolter BF, Ellis M, Curtis SE, Parr ENI, Webel DM.. Feeder location did not affect performance of weeling pigs in large groups. Journal of Animal Science 2009; 78: 2784-2789.

Wroe S, Huber DR, Lowry M, Mchenry C, Moreno K, Clausen P, Ferrara TL, Cunningham E, Dean MN, Summers AP. Three-dimensional computer analysis of white shark jaw mechanics, how hard can a great white bite?. Journal of Zoology 2008; 276: 336-342.

Wu G, Zeng L, Ji L. Measuring the Wing Kinematics of a Moth (Helicoverpa Armigera) by a Two-Dimensional Fringe Projection Method. Journal of Bionic Engineering 2008; 5: 138-142.
Yoganandan N, Pintar FA, Cusick JF. Biomechanical analyses of whiplash injuries using an experimental model. Accident Analysis and Prevention 2002; 34: 663-671.

Yo T, Vilariño M, Faure JM, Picard M. Feed pecking in young chickens: new techniques of evaluation. Physiology \& Behavior 1997; 61: 803-810.

Zang JJ, Piao XS, Huang DS, Wamg JJ, Ma X, Ma YX. Effects of Feed Particle Size and Feed Form on Growth Performance, Nutrient Metabolizability and Intestinal Morphology in Broiler Chickens. Asian-Australasian Journal of Animal Sciences 2009; 22(1): 107-112.

Zeigler H, Levitt P, Levine R. Eating in the pigeon (Columba livia): movement patterns, stereotypy, and stimulus control. Journal of Comparative Physiology and Psychology 1980; 94: 783-794.

Zweers GA. Pecking of the Pigeon (Columba livia L.). Behaviour 1982; 81(2/4): 173-230. 